Original Article

\title{
IN VITRO TOTAL PHENOLICS, FLAVONOIDS CONTENTS, ANTIOXIDANT AND ANTIMICROBIAL ACTIVITES OF VARIOUS SOLVENT EXTRACTS FROM THE MEDICINAL PLANT PHYSALIS MINIMA LINN
}

\author{
VENKANNA BANOTHU1, UMA ADEPALLY1*, JAYALAKSHMI LINGAM²
}

1Department of Bio-Technology, Centre for Bio-Technology, Institute of Science and Technology, Jawaharlal Nehru Technological University Hyderabad, Kukatpally, Hyderabad 500085, Telangana State, India, ${ }^{2}$ Department of Microbiology, Osmania Medical College, Hyderabad, Telangana, India

Email: vedavathi1@jntuh.ac.in

Received: 15 Dec 2016 Revised and Accepted: 17 Jan 2017

\section{ABSTRACT}

Objective: To estimate the in vitro total phenolics, flavonoids contents, antioxidant and antimicrobial activities of various solvent extracts from the medicinal plant Physalis minima Linn.

Methods: The crude bioactive were extracted from the dried powder of Physalis minima using methanol, ethyl acetate, chloroform and hexane solvents. Total phenolic content (TPC) and total flavonoid content (TFC) were estimated using Folin-Ciocalteu and aluminium chloride colorimetric methods respectively. 2,2-diphenyl-1-picrylhydrazyl (DPPH), 2,2'-azino-bis-(3-ethylbenzothiazoline-6-sulphonic acid) (ABTS) and ferric reducing antioxidant power (FRAP) assays were used to determine the in vitro antioxidant capacity. The antimicrobial assay was done through agar well diffusion; minimum inhibitory concentration (MIC) and minimum bactericidal concentration (MBC) were determined using broth microdilution methods against the Gram-negative bacteria (Klebsiella pneumoniae, Escherichia coli, Pseudomonas aeruginosa, Proteus vulgaris) and Gram-positive bacteria (Staphylococcus aureus).

Results: TPC expressed as gallic acid equivalents (GAE) ranged from $60.27 \pm 1.73-151.25 \pm 2.50 \mathrm{mg}$ GAE/g dry weight, and TFC expressed as quercetin equivalents $(\mathrm{QE})$ ranged from $56.66 \pm 0.80-158.84 \pm 2.30 \mathrm{mg} \mathrm{QE} / \mathrm{g}$ dry weight. Methanol extract showed the highest antioxidant activity followed by ethyl acetate, chloroform, hexane extract and the $\mathrm{IC}_{50}$ values of methanol extract for scavenging DPPH and ABTS free radicals were $280.23 \pm 5.75-173.40 \pm 0.38 \mu \mathrm{g} / \mathrm{ml}$, respectively. All the extracts have shown potent antimicrobial activity for the zone of inhibition ranged from $9-35$ $\mathrm{mm}$; MICs and MBCs values ranged from $0.125-4.0$ and $0.25-8.0 \mathrm{mg} / \mathrm{ml}$, respectively towards tested pathogenic species.

Conclusion: The comprehensive analysis of the present results demonstrated that Physalis minima possess high potential antioxidant properties which could be used as a viable source of natural antioxidants in treating infections caused by above-mentioned pathogens.

Keywords: Free radical scavenging activity, In vitro assays, Organic solvents, Physalis minima, Agar well diffusion

(c) 2016 The Authors. Published by Innovare Academic Sciences Pvt Ltd. This is an open access article under the CC BY license (http://creativecommons.org/licenses/by/4.0/)

DOI: http://dx.doi.org/10.22159/ijpps.2017v9i3.16635

\section{INTRODUCTION}

Medicinal plants are plants that have at least one of their parts (leaves, stem, barks or roots) used for therapeutic purposes [1]. The availability and relatively cheaper cost of medicinal plants make them more attractive as therapeutic agents when compared to modern medicine [2]. World plant biodiversity is the largest source of herbal medicine, and still, about $60-80 \%$ world population rely on plant-based medicines which are being used since the ancient ages as traditional health care system. India is endowed with a rich wealth of medicinal plants, which ranked our country in the list of top producers of herbal medicine. Many medicinal plants were found to possess antibacterial, antifungal and insecticidal properties against wide spectra of organisms. Many active phytochemicals like flavonoids, terpenoids, vitamins and alkaloids, etc. were found to be responsible for these activities. With the advance in phytochemical techniques, several active principles of many medicinal plants have been isolated and introduced as valuable drugs in the modern system of medicine [3].

Antioxidants are compounds that block the oxidative procedures and thereby reduce the adverse effects of free radicals. Antioxidants also protect the plants from damage caused by abiotic stress. An imbalance between harmful free radicals and defensive antioxidants leads to oxidative stress which results in the development of chronic and degenerative diseases such as autoimmune disorders, cancer, arthritis, ageing neurodegenerative and cardiovascular disorders [4]. The most common free radicals are hydroxyl $\left(\mathrm{OH}^{-}\right)$, superoxide anion $\left(\mathrm{O}_{2}^{-}\right)$and nitric monoxide (NO-). Other molecules like hydrogen peroxide $\left(\mathrm{H}_{2} \mathrm{O}_{2}\right)$ and peroxynitrite (ONOO-) also generate free radicals through various chemical reactions [5]. The systemic screening of antimicrobial plant extracts represents a continuous effort to find new compounds with the potential to act against multi-resistant pathogenic bacteria and fungi [6].

The plant selected for the present study is Physalis minima Linn, the wild Gooseberry or Sunberry or Ground cherry, a pantrophical annual herb belonging to Solanaceae family is distributed throughout India. The fruit is edible, yellowish and encapsulated in the papery cover which is a good source of vitamin $\mathrm{C}$ and is considered to be a diuretic, purgative and used to relieve pain (analgesic action) and cure spleen disorder [7, 8].

The notable medicinal properties reported for the plant are antidiabetic, antiallergic, antileprotic, antiperiodic, anticancer, antispasmodic, antimalarial, immune modulators, alpha-glucosidase inhibitory and anti neoplasatic activities [9-11] due to which Physalis plants were used for centuries as medicinal herbs and recent studies have confirmed their therapeutic properties [12]. The plant is also used as tonic, laxative, applied in inflammations, enlargement of the spleen and as a helpful remedy in ulceration of the bladder. The leaves are crushed and applied over snake bite site to avoid the adverse effects of venom [7].

Thus, the present study involves estimation of in vitro total phenolics, flavonoids contents, antioxidant and antimicrobial activities of various solvent extracts from the medicinal plant Physalis minima Linn. 


\section{MATERIALS AND METHODS}

\section{Chemicals and reagents}

2,2-azino-bis-(3-ethylbenzothiazoline-6-sulphonic acid) diammonium salt (ABTS), potassium persulfate $\left(\mathrm{K}_{2} \mathrm{~S}_{2} \mathrm{O}_{8}\right)$, 2,2-diphenyl-1picrylhydrazyl (DPPH), hydrogen peroxide $\left(\mathrm{H}_{2} \mathrm{O}_{2}\right)$, 2,4,6-tripyridyl-striazine (TPTZ), gallic acid, quercetin, butylated hydroxyl toluene (BHT), ascorbic acid, Mueller-Hinton agar and broth were obtained from Sigma-Aldrich Chemicals (St Louis, MO, USA). All other chemicals are of analytical grade and were purchased from Merck Limited (Mumbai, India).

\section{Preparation of extracts}

The leaf and stem mixture of the plant Physalis minima Linn were collected from the Eastern Ghats, Vishakapatnam, Andhra Pradesh, India during March 2013, their identity was authenticated at Regional Agriculture Research Centre (RARC), Guntur, Andhra Pradesh, India and a specimen has been preserved at departmental herbarium (Voucher number: AB\#2059). The plant mixture was shade dried and made into coarse powder. The powder (250 g) was soaked sequentially with hexane, chloroform, ethyl acetate and methanol each 6-10 d at room temperature in a $10 \mathrm{l}$ aspirator jar to collect the extracts. These extracts were evaporated by using a rotavapor for further studies. All the extracts were preserved in a refrigerator at $4{ }^{\circ} \mathrm{C}$.

\section{Total phenolic content}

The total phenolic content (TPC) of different extracts was estimated using Folin-Ciocalteu (FC) method [15] with few modifications. The calibration curve was constructed with different concentrations of gallic acid $(20-500 \mu \mathrm{g} / \mathrm{ml})$ as the standard. Briefly, $1 \mathrm{ml}$ of crude extract $(1000 \mu \mathrm{g} / \mathrm{ml})$ was added to $3 \mathrm{ml}$ of distilled water. The sample was then mixed thoroughly with $1 \mathrm{ml}$ of Folin-Ciocalteu reagent (Previously diluted 6 fold with distilled water $(1: 6, v / v)$, followed by the addition of $2 \mathrm{ml}$ of $20 \%(\mathrm{w} / \mathrm{v}$ ) sodium carbonate $\left(\mathrm{Na}_{2} \mathrm{CO}_{3}\right)$. After $30 \mathrm{~min}$ of incubation at room temperature in the dark, the absorbance of the sample and the standard was measured at $765 \mathrm{~nm}$. Distilled water was used as the reagent blank. The TPC of the sample was determined by using linear regression equation obtained from the calibration curve of gallic acid. The content of total phenolic compounds was calculated as mean $\pm \mathrm{SD}(\mathrm{n}=3)$ and expressed as milligrams ( $\mathrm{mg}$ ) of gallic acid equivalents (GAE) per gram (g) of the plant (dry extract).

\section{Total flavonoid content}

The total flavonoid content (TFC) of different extracts was determined using aluminium chloride colorimetric method [16] with slight modification. The calibration curve was plotted with different concentrations of quercetin $(20-100 \mu \mathrm{g} / \mathrm{ml})$ is used as a standard. In brief, $1 \mathrm{ml}$ of plant extract $(1000 \mu \mathrm{g} / \mathrm{ml})$ was mixed with $0.1 \mathrm{ml}$ of $10 \%$ aluminium chloride $\left(\mathrm{AlCl}_{3}\right)$ solution, $0.1 \mathrm{ml}$ of $1 \mathrm{M}$ potassium acetate $\left(\mathrm{C}_{2} \mathrm{H}_{3} \mathrm{KO}_{2}\right)$ solution and $2.8 \mathrm{ml}$ of double distilled water in a test tube. After $30 \mathrm{~min}$ of incubation at room temperature, the absorbance of the sample and standard was measured at $415 \mathrm{~nm}$ with a Ultraviolet-visible spectrophotometer (Shimadzu, Japan). A solution containing all reagents except aluminium chloride, which is replaced by the same amount of distilled water, is used as a blank. The TFC of the sample was determined by using linear regression equation obtained from the calibration standard curve of quercetin. The content of total flavonoid compounds was calculated as mean $\pm \mathrm{SD}(\mathrm{n}=3)$ and was expressed as milligram $(\mathrm{mg})$ of quercetin equivalent $(\mathrm{QE})$ per gram $(\mathrm{g})$ of the plant (dry extract).

\section{DPPH radical scavenging activity assay}

The DPPH radical scavenging activity of all the extracts was evaluated by the method described by Lee JY et al., [17] with slight modification. Ascorbic acid $(2.5-15 \mu \mathrm{g} / \mathrm{ml})$ and butylated hydroxytoluene (BHT) $(20-500 \mu \mathrm{g} / \mathrm{ml})$ were used as the standard. Plant extract $(1 \mathrm{ml})$ at different concentrations $(100-6500 \mu \mathrm{g} / \mathrm{ml})$ were treated with $1 \mathrm{ml}$ of $0.2 \mathrm{mmol}$ DPPH (2,2-diphenyl-1picrylhydrazyl) in ethanol solution. The reaction mixture was incubated in the dark at room temperature for $30 \mathrm{~min}$. The absorbance of the sample and standards was measured at $517 \mathrm{~nm}$.
The ability of the plant extract and standard to scavenge the DPPH radical was calculated as percentage inhibition of absorbance by using the following formula and IC ${ }_{50}$ values were determined.

$$
\text { DPPH scavenging activity }(\%)=\left[\left(\left(\mathrm{A}_{\text {control }}-\left(\mathrm{A}_{\text {Sample- }} \mathrm{A}_{\text {sample }}\right.\right.\right.\right.
$$$$
\text { blank) }) / A_{\text {Control }} \text { x } 100
$$

Where $\mathrm{A}_{\text {Control }}$ indicates the absorbance of control containing $1 \mathrm{ml}$ of DPPH and $1 \mathrm{ml}$ of ethanol. A sample is the absorbance of the sample. Due to the high concentration, the sample also absorbs at this wavelength, so it is required to perform the blank measurement. A Sample blank is the absorbance of sample blank containing $1 \mathrm{ml}$ of plant extract and $1 \mathrm{ml}$ ethanol. Sample blank was prepared separately for each concentration.

\section{Free radical scavenging ability by the use of a stable ABTS} radical cation assay

The stock solutions of $7 \mathrm{mmol}$ ABTS [2,2'-azino-bis-(3ethylbenzthiazoline-6-sulphonic acid) diammonium salt] and 2.45 mmol potassium persulfate $\left(\mathrm{K}_{2} \mathrm{~S}_{2} \mathrm{O}_{8}\right)$ was prepared in ethanol and water (1:1) mixture [18]. The ABTS reagent was prepared by mixing equal volumes of ABTS and $\mathrm{K}_{2} \mathrm{~S}_{2} \mathrm{O}_{8}$ stock solutions. The mixture was allowed to react at room temperature for $12-16 \mathrm{~h}$ in the dark to allow the generation of ABTS radical cation (ABTS*+). The ABTS radical solution was then diluted with ethanol and water mixture to obtain an absorbance of $0.700 \pm 0.020$ at $734 \mathrm{~nm}$. Ascorbic acid (1-3 $\mu \mathrm{g} / \mathrm{ml})$ and BHT $(1-5 \mu \mathrm{g} / \mathrm{ml})$ were used as standards. To determine the scavenging activity, plant extract $(1 \mathrm{ml})$ at different concentrations $(80-2500 \mu \mathrm{g} / \mathrm{ml})$ were reacted with $1 \mathrm{ml}$ of diluted ABTS solution. The mixture was allowed to incubate at room temperature for $6 \mathrm{~min}$, and the absorbance was recorded at $734 \mathrm{~nm}$. The ability of the plant extract and standard to scavenge the ABTS radical was calculated as a percentage of inhibition by using the following formula, and $\mathrm{IC}_{50}$ values were determined.

$$
\begin{gathered}
\text { ABTS scavenging activity }(\%)=\left[\left(\left(\text { Acontrol-}_{\text {- }}\right.\right.\right. \text { (Asample-Asample } \\
\text { blank } \left.)) / A_{\text {Control }}\right] \times 100
\end{gathered}
$$

Where $\mathrm{A}_{\text {control }}$ indicates the absorbance of control containing $1 \mathrm{ml}$ of diluted ABTS radical solution and $1 \mathrm{ml}$ of ethanol and water mixture. Asample is the absorbance of the sample. Asample blank is the absorbance of sample blank containing $1 \mathrm{ml}$ of ethanol and water mixture and 1 $\mathrm{ml}$ of plant extract. Ethanol and water mixture was used as blank solution. Sample blank was prepared separately for each concentration.

\section{Ferric reducing antioxidant power (FRAP) activity assay}

The ferric reducing ability of plant extracts was measured by the method described by Benzie and Strain [19]. FRAP reagent was a mixture (10:1:1, v/v/v) of $300 \mathrm{mmol}$ sodium acetate buffer $(\mathrm{pH} 3.6)$, $10 \mathrm{mmol}$ TPTZ [2,4,6-tris(2-pyridyl-s-triazine)] in $40 \mathrm{mmol} \mathrm{HCL}$ and $\mathrm{FeCl}_{3} \cdot 6 \mathrm{H}_{2} \mathrm{O}(20 \mathrm{mmol})$. The calibration curve was plotted with different concentrations of ferrous sulphate $\left(\mathrm{FeSO}_{4}\right)(0.2-1.0 \mathrm{mmol})$ used as a standard. Ascorbic acid $(100-500 \mu \mathrm{g} / \mathrm{ml})$ and BHT $(100-$ $500 \mu \mathrm{g} / \mathrm{ml}$ ) were used as the reference standards. To determine the ferric ion reducing ability, $100 \mu \mathrm{l}$ of plant extract at different concentrations $(100-500 \mu \mathrm{g} / \mathrm{ml})$ were treated with $3 \mathrm{ml}$ of freshly prepared FRAP reagent. After incubation at $37^{\circ} \mathrm{C}$ for $30 \mathrm{~min}$ the absorbance was measured at $593 \mathrm{~nm}$. The antioxidant capacity based on the ability to reduce ferric ions of the sample was determined by using linear regression equation obtained from the calibration curve of $\mathrm{FeSO}_{4}$ and expressed as $\mathrm{mmol} \mathrm{FeSO}_{4}$ equivalents per gram (g) dry weight of plant extract.

\section{Screening for antimicrobial activity}

\section{Microorganisms and media}

The bacterial strains were procured from Department of Microbiology, Osmania Medical Hospital and Hyderabad, India. The cultures included in this study were Gram-negative bacteria Klebsiella pneumoniae (Isolated from urine), Escherichia coli (isolated from exudate), Pseudomonas aeruginosa (Isolated from exudate) and Proteus vulgaris (Isolated from exudate) and Grampositive bacteria Staphylococcus aureus (Isolated from exudate) which were maintained on Mueller-Hinton agar slants at $4{ }^{\circ} \mathrm{C}$. 


\section{Agar well diffusion method}

The in vitro antimicrobial activity of all the four leaf extracts was tested against the selected bacteria by agar well diffusion method [20] using Muller-Hinton agar as the medium. The agar medium was streaked with the microorganism and an $8 \mathrm{~mm}$ well was made on the agar surface. $100 \mu \mathrm{l}$ of each extract was filled in the well so that the final concentration in each well was $1.6 \mathrm{mg}$. The reference standard was maintained with ceftriaxone $(1 \mathrm{mg} / \mathrm{ml})$. The individual solvents were used as negative control. The plates were incubated for $24 \mathrm{~h}$ at $37{ }^{\circ} \mathrm{C}$. During this period, the test solution diffused and the growth of the inoculated microorganisms was affected. At the end of the incubation period, the zone of clearance was observed and measured in $\mathrm{mm}$. The susceptibility zones measured were the clear zones around the discs killing the bacteria.

Determination of minimum inhibitory concentration (MIC) and minimum bactericidal concentration (MBC)

The minimum inhibitory concentration (MIC) was determined by the micro brothdilution method done in 96 well plates according to standard protocol $[21,6]$. A 2-fold serial dilution of the crude extracts, with an appropriate antibiotic, was prepared. Ceftriaxone $(1 \mathrm{mg} / \mathrm{ml})$ was taken as positive control. Initially, $100 \mu \mathrm{l}$ of MH broth was added to each well. Then $100 \mu \mathrm{l}$ of crude extract or antibiotic was taken from stock solution and dissolved in the first well. Serial dilution was done to obtain different concentrations. The stock concentrations of all the four solvent extracts were $16 \mathrm{mg} / \mathrm{ml}$. Twenty-four-hour culture turbidity was adjusted to match 0.5 McFarland standards which correspond to $1 \times 10^{8} \mathrm{CFU} / \mathrm{ml}$. The standardized suspension $(100 \mu \mathrm{l})$ of bacteria was added to all the wells except the antibiotic control well and the 96 well plates were incubated at $37^{\circ} \mathrm{C}$ for $24 \mathrm{~h}$. After $24 \mathrm{~h}$ of incubation $40 \mu \mathrm{l}$ of MTT (3- (4,5-dimethlthiazol-2-yl)-2,5-diphenyltrazolium bromide) reagent $(0.5 \mathrm{mg} / \mathrm{ml}$ in $1 \mathrm{x}$ PBS) was added to all the wells. MIC was taken as the lowest concentration which did not show any growth which was visually noted from the blue colour developed by MTT. Subcultures were made from clear wells and the lowest concentration that yielded no growth after subculturing was taken as the MBC.

\section{Statistical analysis}

All determinations of total phenolic, flavonoid compounds and antioxidant activity (using different assays) were done in triplicates. Values for each sample were expressed as mean \pm standard deviation (SD) and were subjected to analysis of variance (ANOVA). Statistical analysis was done using Graph Pad Prism Software Version 7.01 (GPPS Inc, California and USA). Correlation between the means was assessed using Dunnett's multiple comparisons test. For antioxidant assays, $1 / \mathrm{IC}_{50}$ value was used to determine the correlation and $\mathrm{P}<0.05$ was considered for statistically significance.

\section{RESULTS}

\section{Total phenolic content}

The total phenolic content (TPC) of the all four extracts of Physalis minima were determined by using Folin-Ciocalteu (FC) method and reported in terms of gallic acid equivalents per gram dry weight of extract showed in table 1 . Hexane extract $(151.25 \pm 2.50$ mg GAE/g dry weight) showed the highest amount of phenolic compounds followed by methanol $(79.30 \pm 1.68 \mathrm{mg} \mathrm{GAE} / \mathrm{g} \mathrm{DW})$, chloroform (68.61 $\pm 2.13 \mathrm{mg} \mathrm{GAE} / \mathrm{g} \mathrm{DW})$ and ethyl acetate (60.27 $\pm 1.75 \mathrm{mg} \mathrm{GAE} / \mathrm{g} \mathrm{DW}$ ) extract when compared to standard gallic acid. The results of the analytical method were validated by linear correlation between concentration and absorbance with $\mathrm{R}^{2}$ value of 0.996 (fig. 1).

Table 1: Total phenolic and total flavonoid content of Physalis minima $(L)$

\begin{tabular}{llll}
\hline S. No. & Name of extracts & \multicolumn{2}{c}{ Equivalents per g dry weight of extract $\mathbf{~} \mathbf{m g} / \mathbf{g})$} \\
\cline { 3 - 4 } & & Total phenolic content (Gallic acid) & Total flavonoid content (Quercetin) \\
\hline 1 & Methanol & $79.30 \pm 1.68$ & $90.64 \pm 1.93$ \\
2 & Ethyl acetate & $60.27 \pm 1.73$ & $158.84 \pm 2.30$ \\
3 & Chloroform & $68.61 \pm 2.13$ & $118.07 \pm 2.14$ \\
4 & Hexane & $151.25 \pm 2.50$ & $56.66 \pm 0.80$ \\
5 & P Value & $\mathrm{P}<0.05$ & $\mathrm{P}<0.05$ \\
\hline
\end{tabular}

The data represent the mean $\pm \mathrm{SD}$ of the three determinants and level of significance (P).

Total phenolic content

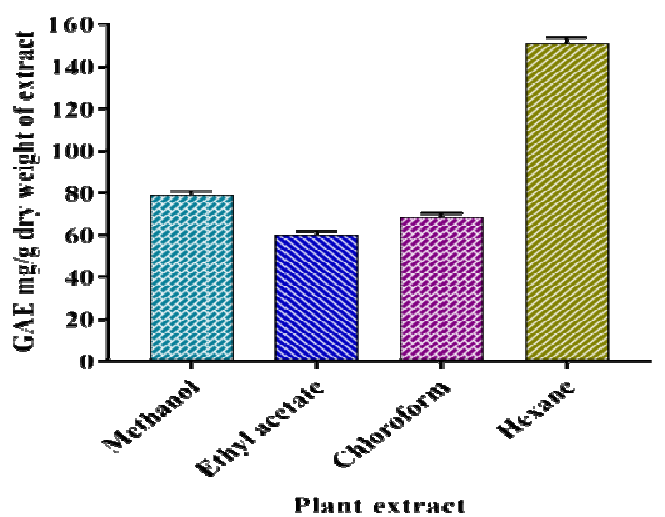

Fig. 1: Total phenolic content (TPC) in various solvent extracts of Physalis minima

\section{Total flavonoid content}

The total flavonoid content (TFC) of all the four extracts of Physalis minima were determined by using the aluminium chloride colorimetric method and reported in terms of quercetin equivalents per gram dry weight of extract (table 1). Ethyl acetate extract
(158.84 $\pm 2.30 \mathrm{mg}$ QE/g dry weight) showed the highest amount of flavonoid content followed by chloroform $(118.07 \pm 2.14 \mathrm{mg} \mathrm{QE} / \mathrm{g}$ DW), methanol $(90.64 \pm 1.93 \mathrm{mg} \mathrm{QE} / \mathrm{g} \mathrm{DW})$ and hexane extract $(56.66 \pm 0.80 \mathrm{mg} \mathrm{QE} / \mathrm{g} \mathrm{DW})$. The results of the analytical method were validated by linear correlation comparison and the $\mathrm{R}^{2}$ value of 0.995 (fig. 2).

Total flavonoid content

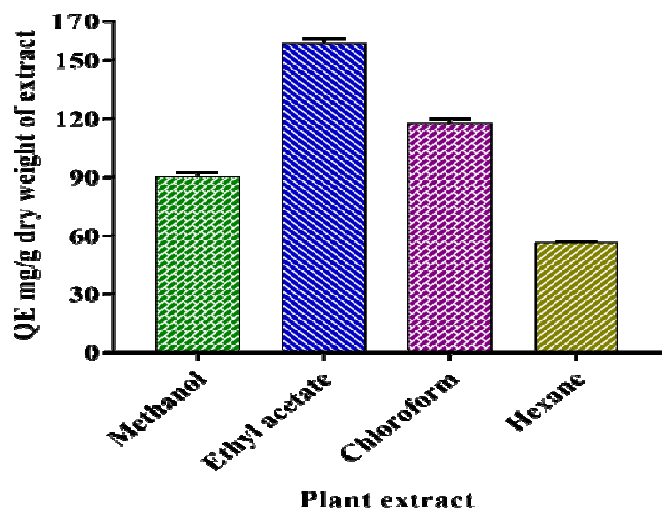

Fig. 2: Total flavonoid content (TFC) in various solvent extracts of Physalis minima 


\section{Free radicals scavenging effect on DPPH assay}

The DPPH radical scavenging activity of plant extracts and standards increased with increase in concentration. The lower $\mathrm{IC}_{50}$ value indicates higher antioxidant activity. Among all the extracts methanol $(280.23 \pm 5.75 \mu \mathrm{g} / \mathrm{ml})$ has the lowest IC ${ }_{50}$ value followed by ethyl acetate $(487.53 \pm 8.71 \mu \mathrm{g} / \mathrm{ml})$, chloroform $(571.70 \pm 6.86 \mu \mathrm{g} / \mathrm{ml})$ and hexane $(5431.46 \pm 68.70 \mu \mathrm{g} / \mathrm{ml})$. The further $\mathrm{IC}_{50}$ value of methanol was less than the IC $\mathrm{C}_{50}$ value of BHT $(458.10 \pm 33.09 \mu \mathrm{g} / \mathrm{ml})$ but was not significantly lower than the $\mathrm{IC}_{50}$ of ascorbic acid $(6.11 \pm 0.44 \mu \mathrm{g} / \mathrm{ml})$. Antioxidant activity of remaining extracts was significantly lower than that of standards (table 2 and fig. 3).

Table 2: DPPH and ABTS radical scavenging activity of standards and plant extracts

\begin{tabular}{|c|c|c|c|c|}
\hline \multirow[t]{2}{*}{ S. No. } & \multirow[t]{2}{*}{ Samples } & \multirow[t]{2}{*}{ Extractions } & \multicolumn{2}{|c|}{$\%$ of Inhibitory effect $\left(\mathrm{IC}_{50} ; \mu \mathrm{g} / \mathrm{ml}\right)$} \\
\hline & & & DPPH & ABTS \\
\hline 1 & Ascorbic acid & - & $6.11 \pm 0.44$ & $3.65 \pm 0.26$ \\
\hline 2 & BHT & - & $458.10 \pm 33.09^{*}$ & $6.57 \pm 0.57$ \\
\hline 3 & Plant & Methanol & $280.23 \pm 5.75^{*}$ & $173.40 \pm 0.38^{*}$ \\
\hline 4 & Plant & Ethyl acetate & $487.53 \pm 8.71^{*}$ & $226.16 \pm 4.19 *$ \\
\hline 5 & Plant & Chloroform & $571.70 \pm 6.86^{*}$ & $263.63 \pm 19.96^{*}$ \\
\hline 6 & Plant & Hexane & $5431.46 \pm 68.70^{*}$ & $2400.73 \pm 21.20^{*}$ \\
\hline
\end{tabular}

The data represent the mean $\pm \mathrm{SD}$ of the three determinants and level of significance; ${ }^{*} \mathrm{P}<0.05$ vs Physalis minima and ascorbic acid was used as control for statistical significance analysis.

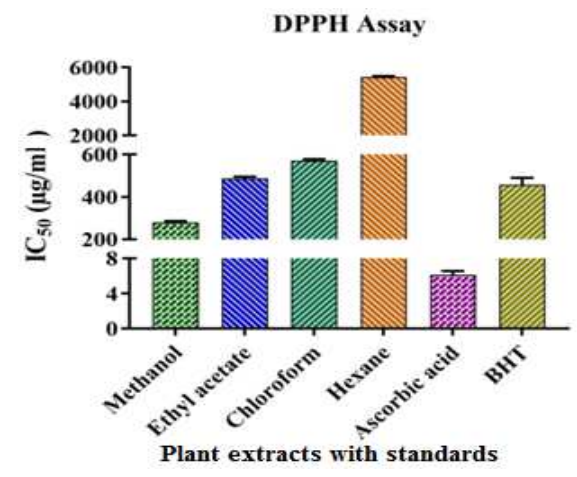

Fig. 3: Free radical scavenging activity (DPPH) of Physalis minima extracts. The y-axis was cut up from 8-200 and 6002000 for better understanding
The correlation between antioxidant capacity determined by DPPH and total flavonoid content $(\mathrm{r}=0.362, \mathrm{P}>0.05)$, total phenolic content $(r=-0.717, P>0.05)$ and FRAP $(r=0.392, P>0.05)$ was not significant. But there was a significant correlation between antioxidant capacity determined by DPPH and ABTS $(r=0.968, \mathrm{P}<0.05)$ assay and were noted in table 3 .

Free radical scavenging ability by the use of a stable ABTS radical cation assay

Free radicals scavenging activity of the plant extracts and standards increased in a concentration-dependent manner and the results were demonstrated in the fig. 4 and table 2.

The decreasing order of ABTS scavenging activity of different extracts was methanol $(173.40 \pm 0.38 \mu \mathrm{g} / \mathrm{ml})>$ ethyl acetate $(226.16 \pm 4.19 \mu \mathrm{g} / \mathrm{ml})>$ chloroform $(263.63 \pm 19.96 \mu \mathrm{g} / \mathrm{ml})$ and $>$ hexane $(2400.73 \pm 21.20 \mu \mathrm{g} / \mathrm{ml})$. The antioxidant activity of plant extract mixture was significantly lower than that of ascorbic acid $(3.65 \pm 0.26 \mu \mathrm{g} / \mathrm{ml})$ and BHT $(6.57 \pm 0.57 \mu \mathrm{g} / \mathrm{ml})$.

Table 3: Correlation matrix of total phenolic, flavonoid content and antioxidant activity measured by three in vitro assays

\begin{tabular}{lllc}
\hline & Total phenolic content & Total flavonoid content & DPPH \\
\hline Total phenolic content & 1 & & ABTS \\
Total flavonoid content & -0.867 & 1 & 1 \\
DPPH & -0.717 & 0.362 & $0.968^{*}$ \\
ABTS & -0.867 & 0.574 & 1 \\
FRAP & -0.890 & 0.808 & 0.392 \\
\hline
\end{tabular}

Level of significance; ${ }^{*} \mathrm{P}<0.05$

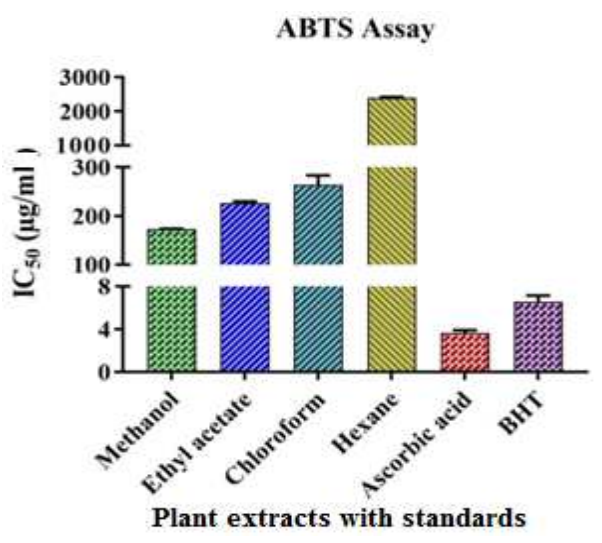

Fig. 4: Free radical scavenging activity (ABTS) of Physalis minima extracts. The y-axis was cut up from 8-100 and 3001000 for better understanding
There was no significant correlation between antioxidant capacity determined by ABTS and total flavonoid content $(\mathrm{r}=0.574, \mathrm{P}>0.05)$, total phenolic content $(\mathrm{r}=-0.867, \mathrm{P}>0.05)$ and FRAP $(\mathrm{r}=0.591$, $\mathrm{P}>0.05$ ) assay and were noted in table 3 .

\section{Ferric reducing antioxidant power (FRAP) activity assay}

The results of FRAP assay obtained with different plant extracts of Physalis minima were shown in fig. 5. At varied concentrations of $\mathrm{FeSO}_{4}(100-500 \mu \mathrm{g} / \mathrm{ml})$, the reducing activity followed the order of chloroform extract>ethyl acetate extract>methanol extract>hexane extract when compared to standards ascorbic acid and BHT.

The above results clearly indicate that chloroform extract has the high reducing activity when compared to other solvent extracts at various concentrations. The results of the analytical method were validated by linear correlation comparison of ferrous sulphate and the $\mathrm{R}^{2}$ value of 0.996 was obtained.

Ferric reducing the antioxidant power of plant extracts was neither significantly correlated with total flavonoid content $(r=0.808$, 
$\mathrm{P}>0.05)$ nor total phenolic content $(\mathrm{r}=-0.890, \mathrm{P}>0.05)$ assay and were noted in table 3.

\section{Screening for antimicrobial activity}

Antimicrobial activity of Physalis minima plant extracts was evaluated against different human pathogens. The results were represented in the table 4 . The zone of inhibition ranges from
13-19 $\mathrm{mm}$ for methanol extract against all the pathogens. The ethyl acetate extract showed inhibition zone diameters of 13-35 $\mathrm{mm}$.

For chloroform extract zone of inhibition ranged from 20-35 mm. Klebsiella pneumoniae were completely inhibited by chloroform extract. Hexane extract showed the minimum zone of inhibitions ranging from 9-13 mm compared to rest of the extracts.

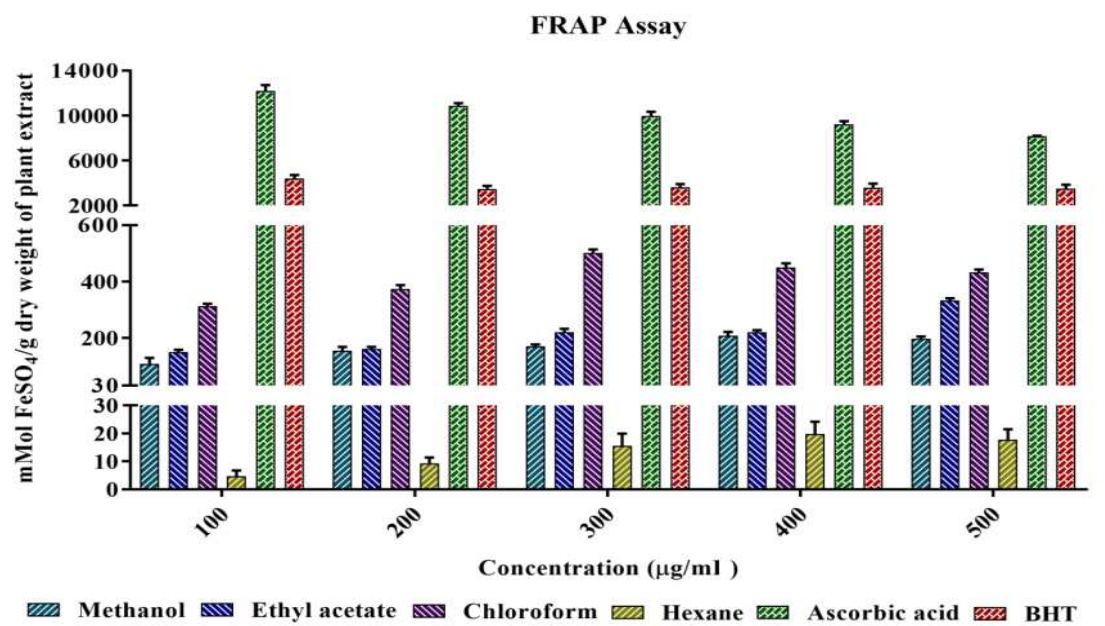

Fig. 5: Free radical scavenging activity (FRAP) of Physalis minima extracts. The y-axis was cut up from 30-30 and 600-2000 for better understanding

Table 4: Zone of inhibition of plant extracts against pathogenic bacteria determined by agar well diffusion method

\begin{tabular}{|c|c|c|c|c|c|c|c|c|c|c|}
\hline \multirow[t]{2}{*}{ Name of microorganisms } & \multicolumn{2}{|l|}{ ME } & \multicolumn{2}{|l|}{ EA } & \multicolumn{2}{|l|}{$\mathbf{C H}$} & \multicolumn{2}{|l|}{ HE } & \multicolumn{2}{|c|}{ Ceftriaxone } \\
\hline & $\mathbf{m m}$ & $\%$ & $\mathbf{m m}$ & $\%$ & $\mathbf{m m}$ & $\%$ & $\mathbf{m m}$ & $\%$ & $\mathbf{m m}$ & $\%$ \\
\hline \multirow[t]{2}{*}{ Staphylococcus aureus } & $13 \pm$ & 76.5 & $23 \pm$ & 135.3 & $30 \pm$ & 176.5 & $11 \pm$ & 64.8 & $17 \pm$ & 100 \\
\hline & 0.51 & & 0.85 & & 0.35 & & 0.25 & & 0.15 & \\
\hline Escherichia & $13 \pm$ & 72.2 & $13 \pm$ & 72.2 & $33 \pm$ & 183.3 & $10 \pm$ & 55.6 & $18 \pm$ & 100 \\
\hline coli & 1.00 & & 0.24 & & 0.25 & & 0.49 & & 0.30 & \\
\hline \multirow[t]{2}{*}{ Klebsiella pneumoniae } & $19 \pm$ & 90.4 & $35 \pm$ & 166.7 & $30 \pm$ & 142.9 & $13 \pm$ & 61.9 & $21 \pm$ & 100 \\
\hline & 0.52 & & 0.65 & & 0.25 & & 0.51 & & 0.20 & \\
\hline Proteus & $14 \pm$ & 77.8 & $22 \pm$ & 122.2 & IC & - & $09 \pm$ & 50.0 & $18 \pm$ & 100 \\
\hline vulgaris & 0.31 & & 0.66 & & & & 0.26 & & 0.15 & \\
\hline \multirow[t]{2}{*}{ Pseudomonas aeruginosa } & $14 \pm$ & 42.4 & $20 \pm$ & 60.6 & $25 \pm$ & 75.8 & $10 \pm$ & 30.3 & $33 \pm$ & 100 \\
\hline & 0.28 & & 0.36 & & 0.20 & & 0.30 & & 0.15 & \\
\hline
\end{tabular}

$\mathrm{HE}=$ Hexane, $\mathrm{CH}=$ Chloroform, $\mathrm{EA}=$ Ethyl acetate, $\mathrm{ME}=$ Methanol and IC $=$ Isolated colony. Inhibitory zones in mm, represented as mean $\pm \mathrm{SD}$ values $(n=3)$. Percentage inhibition included.

The minimum inhibitory concentrations and minimum bactericidal concentrations were determined and noted in table 5. MIC of the Physalis minima plant extracts range from 0.4-5.0 $\mathrm{mg} / \mathrm{ml}$ for Staphylococcus aureus, $1.0-4.0 \mathrm{mg} / \mathrm{ml}$ for Escherichia coli, $1.0-2.0 \mathrm{mg} / \mathrm{ml}$ for Proteus vulgaris, in case of Klebsiella pneumoniae it range from $0.125-0.5 \mathrm{mg} / \mathrm{ml}$ and it is $1.0-4.0$ $\mathrm{mg} / \mathrm{ml}$ for Pseudomonas aeruginosa. The MBC of the plant extracts range from 4.0-8.0 $\mathrm{mg} / \mathrm{ml}$ for Staphylococcus aureus and Escherichia coli. For Klebsiella pneumoniae it range from 0.25-1.0 $\mathrm{mg} / \mathrm{ml}$, for Proteus vulgaris it was $4.0 \mathrm{mg} / \mathrm{ml}$ and for Pseudomonas aeruginosa range from 4.0 to $8.0 \mathrm{mg} / \mathrm{ml}$. The plant extracts confirmed antibacterial activity towards all the pathogenic species. All the extracts showed equal inhibition of the tested pathogens.

Table 5: MIC and MBC of plant extracts against pathogenic bacteria

\begin{tabular}{|c|c|c|c|c|c|c|c|c|c|c|}
\hline \multirow[t]{3}{*}{ Strains } & \multicolumn{10}{|c|}{ Different solvent extracts $(\mathrm{mg} / \mathrm{ml})$} \\
\hline & \multicolumn{2}{|c|}{ ME } & \multicolumn{2}{|c|}{ EA } & \multicolumn{2}{|l|}{$\mathbf{C H}$} & \multicolumn{2}{|l|}{ HE } & \multicolumn{2}{|c|}{ Ceftriaxone } \\
\hline & MIC & MBC & MIC & MBC & MIC & MBC & MIC & MBC & MIC & MBC \\
\hline S. aureus & 0.4 & 8.0 & 4.0 & 8.0 & 4.0 & 8.0 & 0.5 & 4.0 & 0.062 & 0.125 \\
\hline E. coli & 0.4 & 8.0 & 2.0 & 4.0 & 4.0 & 8.0 & 1.0 & 4.0 & 0.031 & 0.062 \\
\hline K. pneumoniae & 0.5 & 1.0 & 0.5 & 1.0 & 0.5 & 1.0 & 0.125 & 0.25 & 0.062 & 0.125 \\
\hline P. vulgaris & 2.0 & 4.0 & 2.0 & 4.0 & 1.0 & 4.0 & 2.0 & 4.0 & 0.062 & 0.125 \\
\hline P. aeruginosa & 2.0 & 8.0 & 4.0 & 8.0 & 4.0 & 8.0 & 1.0 & 4.0 & 0.062 & 0.125 \\
\hline
\end{tabular}

$\mathrm{HE}=$ Hexane, $\mathrm{CH}=$ Chloroform, $\mathrm{EA}=$ Ethyl acetate, $\mathrm{ME}=$ Methanol and $\mathrm{MIC}=$ Minimum Inhibitory Concentration, $\mathrm{MBC}=\mathrm{Minimum}$ Bactericidal Concentration. The table represents the best MIC and MBC value among the three repeats. 


\section{DISCUSSION}

Medicinal plants were of great importance to the health of individuals and communities [22]. Phytochemical analysis conducted on the plant extracts revealed the presence of constituents which are known to exhibit medicinal as well as physiological activities. Several studies have described the antioxidant properties of different parts of various medicinal plants which are rich in phenolic compounds [23]. Natural antioxidants mainly come from plants in the form of phenolic compounds, such as flavonoids, phenolic acids and tocopherols etc [24].

Plant-derived phenolic compounds include phenolic acids, flavonoids, tannins and less common stilbenes and lignans $[25,26]$. They are a rich source of antioxidants. Phenolics act as antioxidants by scavenging radical species, chelating trace metals like $\mathrm{Cu}^{+}$or $\mathrm{Fe}^{2+}$ that are responsible for free radical production [27]. Total phenolics are considered as more powerful antioxidants than vitamin $\mathrm{C}$ and $\mathrm{E}$ and carotenoids in vitro. Phenolic compounds reduce free radicals by rapidly donating hydrogen atoms and thereby breaking the chain of reaction that lead to free radical formation [28]. Hexane extract contains the highest amount of phenolic compounds followed by methanol, chloroform and ethyl acetate extract. Total phenolic content was more in non-polar solvents than in polar solvent.

Flavonoids are hydroxylated phenolic substances known to be synthesized by plants in response to microbial infection and they have been found to be antimicrobial substances against a wide array of microorganisms in vitro [29,33]. The antioxidative properties of flavonoids are due to several different mechanisms, such as scavenging of free radicals, chelation of metal ions, such as iron and copper and inhibition of enzymes responsible for a free radical generation [27]. The ethyl acetate extract has great free radical scavenging property and also contains liberal amount of flavonoid component followed by chloroform, methanol and hexane extract. The total flavonoid content was more in polar solvents than in nonpolar solvents.

Several mechanisms have been proposed by which antioxidants act against free radicals $[30,34,35]$. Some of the mechanisms are by donating a hydrogen atom or electron to radical, scavenging free radical, chelating metal ions, inhibiting $\beta$-carotene bleaching and quenching singlet oxygen. Based on the chemical reactions involved, major antioxidants assay method can be divided into two types. They are hydrogen atom transfer (HAT) and single electron transfer (ET). Each assay specifically detects any one of the ability of antioxidant. Therefore it was necessary to use more than one type of antioxidant assays [30, 31].

In the present study, the antioxidant activity of plant extracts was determined in vitro with different assays like DPPH, ABTS radical scavenging and FRAP assays. Among these assay, DPPH and FRAP assays are ET based assays. On the other hand ABTS radical scavenging assays measure the ability of an antioxidant to transfer hydrogen (HAT) to destabilize the free radicals there by neutralizing it $[30,27]$. Antioxidant properties were evaluated and lower $\mathrm{IC}_{50}$ values indicate higher antioxidant activity. Ethyl acetate extract showed the highest activity and hexane extract showed the least activity.

As Physalis minimum was found to give the most powerful antimicrobial extract, the antimicrobial effectiveness of plants was supposed to be due to the presence of phenolic compounds, tannins, flavonoids and essential oils [32, 36]. It was exciting to a memorandum that even crude extracts of these plants demonstrated good quality activity against multidrug resistant strains. The present studies revealed that all the plant extracts had inhibited the growth of Klebsiella pneumoniae, Escherichia coli, Pseudomonas aeruginosa, Proteus vulgaris and Staphylococcus aureus.

\section{CONCLUSION}

On the basis of results observed in the present study, it was clear that hexane and ethyl acetate extract of Physalis minima leaf and stem contains an abundant amount of phenolic and flavonoid compounds which possess high antioxidant and free radical scavenging activities. The antimicrobial properties of the plant in the current study are mainly due to presence of large amounts of flavonoid components. The phytochemical constituents of this plant may be responsible for their efficacy in the treatment of skin diseases. Further work has to be carried out to isolate, purify and characterize the phyto constituents of this plant responsible for bioactive study.

\section{ACKNOWLEDGMENT}

Authors are thankful to University Grant Commission-New Delhi, India (Grant No: F1-17.1/2011-12/RGNF-ST-AND-9020) for providing RGNF Fellowship and Financial Assistance to carry out this research work and thankful to faculty members, Institute of Science and Technology, Jawaharlal Nehru Technological University Hyderabad, Hyderabad for their constant encouragement and their valuable suggestions. The authors acknowledge to Dr. K. Guravareddy, Scientist of Regional Agriculture Research Centre (RARC), Guntur, Andhra Pradesh, India for his kind help.

\section{CONFLICTS OF INTERESTS}

The authors declare that there are no potential conflicts of interest.

\section{REFERENCES}

1. Bruneton J. Pharmacognosie, Phytochimie, Plantes medicinales. $2^{\text {nd }}$ edition. Lavoisier, Paris; 1993. p. 41-54.

2. Agbor AG, Ngogang JY. Toxicity of herbal preparations. Cam J Ethanobot 2005;1:23-8.

3. Sasidharan S, Chen Y, Saravanan D, Sundram KM, Latha YL. Extraction, isolation and characterization of bioactive compounds from plants' extracts. Afr J Tradit Complementary Altern Med 2011;8:1-10.

4. Rajkapoor B, Burkan ZE, Kumar RS. Oxidants and human diseases: role of antioxidant medicinal plants-a review. PhOL 2010;1:1117-31.

5. Gilgun-Sherki Y, Melamed E, Offen D. Oxidative stress inducedneurodegenerative diseases: the need for antioxidants that penetrate the blood brain barrier. Neuropharmacol 2001;40:959-75.

6. Nayeemulla S, Sudharshana MS, Umesha S, Hariprasad P. Antimicrobial activity of Rauvolfia tetraphylla and Physalis minima leaf and callus extracts. Afr J Biotech 2006;5:946-50.

7. Sasikala RP, Meena KS. Molecular docking studies and admet properties of compounds from Physalis minima l. leaves, root and fruit. Innov J Life Sci 2016;4:21-5.

8. Pratheeba M, Umaa Rani K, Ramesh B. Hepatoprotective activity of Physalis minima against paracetomal induced Hepatic Damage in Rats. Int J Curr Res Biosci Plant Biol 2014;1:61-9.

9. Angamuthu J, Ganapathy M, Evanjelene VK, Ayyavuv N, Padamanabhan V. Evaluation of phytochemical analysis and antimicrobial activity of leaf and fruit extracts of Physalis minima. Int J Emerging Technol Adv Eng 2014;4:462-5.

10. Daya LC, Vaghasiya HU. A phyto-pharmacological overview on Physalis minima Linn. Indain J Nat Prod Resour 2012;3:477-82.

11. Nathiya M, Dorcus D. Preliminary phytochemical and antibacterial studies on Physalis minima Linn. Int J Curr Sci 2012;24-30.

12. Lan YH, Chang FR, Pan MJ, Wu CC, Wu SJ, Chen SL, et al. New cytotoxic withanolides from Physalis peruviana. Food Chem 2009;116:462-9.

13. Ganesh S, Vennila JJ. Phytochemical analysis of Acanthus ilicifolius and Avicennia officinalis by GC-MS. Res J Phytochem 2011;5:60-5.

14. Zaman R, Parvez M, Jakaria MD, Ali MS, Hoque SA. Phytochemical screening, in vitro cytotoxic and antimicrobial activity of methanolic extract of leaves of ficus sagittatavahl. Inov J Life Sci 2016;4:12-5.

15. Alhakmani F, Kumar S, Khan SA. Estimation of total phenolic content, in vitro antioxidant and anti-inflammatory activity of flowers of Moringa oleifera. Asain Pac J Trop Biomed 2013;3:623-7.

16. Aruna K, Sharma RA. Estimation of total phenol, flavonoid contents and DPPH free radical scavenging activity of Oxalis corniculata Linn. Int J Biol Pharm Res 2015;6:178-81. 
17. Lee JY, Hwang WI, Lim ST. Antioxidant and anticancer activities of organic extracts from Platycodon grandiflorum A. De Candolle roots. J Ethnopharmacol 2004;93:409-15.

18. Guedes AC, Amaro HM, Giao MS, Malcata FX. Optimization of ABTS radical cation assay specifically for determination of antioxidant capacity of intracellular extracts of microalgae and cyanobacteria. Food Chem 2013;138:638-43.

19. Benzie IFF, Strain JJ. The ferric reducing ability of plasma (FRAP) as a measure of "antioxidant power": the FRAP assay. Anal Biochem 1996;239:70-6.

20. Mandal S, Patra A, Samanta A, Roy S, Mandal A, Mahapatra TD, et al. Analysis of phytochemical profile of Terminalia arjuna bark extract with antioxidative and antimicrobial properties. Asian Pac J Trop Biomed 2013;3:960-6.

21. National Committee for Clinical Laboratory Standards: Methods for dilution, antimicrobial susceptibility tests for bacteria that grow aerobically. Approved standard: NCCLS document; 2000. p. M7-A4.

22. Pascaline J, Charles M, Lukhoba C, George O. Phytochemical constituents of some medicinal plants used by the Nandis of South Nandi district, Kenya. J Anim Plant Sci 2011;9:1201-10.

23. Krings U, Berger RG. Antioxidant activity of roasted foods. Food Chem 2001;72:223-9.

24. Ali SS, Kasoju N, Luthra A, Singh A, Sharanabasava H, Sahu A, et al. Indian medicinal herbs as a source of antioxidants. Food Res Int 2008:41:1-15.

25. Nandita D, Islam ME, Jahan N, Islam MS, Khan A, Islam MR, et al. Antioxidant activities of ethanol extracts and fractions of Crescentia cujete leaves and stem bark and the involvement of phenolic compounds. BMC Complementary Altern Med 2014;14:45.

26. Dai J, Mumper RJ. Plant phenolics: extraction, analysis and their antioxidant and anticancer properties. Molecules 2010;15: 7313-52.

27. Apak R, Guçlu K, Demirata B, Ozyurek M, Çelik SE, Bektaşoglu B, et al. Comparative evaluation of various total antioxidant capacity assays applied to phenolic compounds with the CUPRAC assay. Molecules 2007;12:1496-47.

28. Ndhlala AR, Mack M, Staden JV. Natural antioxidants: fascinating or mythical biomolecules? Molecules 2010; 15:6905-30

29. Shashank K, Pandey Ak. Chemistry and biological activities of flavonoids: an overview. Sci World J 2013;16. http://dx.doi.org/10.1155/2013/162750.

30. Huang D, Ou B, Prior RL. The chemistry behind antioxidant capacity assays. J Agric Food Chem 2005;53:1841-56.

31. Prior RL, Wu X, Schaich K. Standardized methods for the determination of antioxidant capacity and phenolics in food and dietary supplements. J Agric Food Chem 2005;53:4290-302.

32. Aboaba 0, Efuwape BM. Antibacterial properties of some Nigerian species. Biol Res Commun 2001;13:183-8.

33. Tulasi CD, Rani AS, Manjula B. Screening of phytochemicals, TLC profiling, total lavonoid and phenolics content, antioxidant activity and antimicrobial activity of Ficus enghalensis linn and Ficus religiosa linn latex. Int J Pharm Pharm Sci 2015;7:480-5.

34. Prabhjot SJ, Gagandeep K. Comparative analysis of antioxidant activity and phytochemical contents in ethanolic leaf extracts of in vitro and field grown Withania somnifera. Asian J Pharm Clin Res 2016;9:239-44.

35. Adhiraj D, Manjula R, Krishnendu A. Phytochemical analysis and in vitro antioxidant activity of a wild edible mushroom Entoloma lividoalbum. Asian J Pharm Clin Res 2015;8:171-4.

36. Beena J, Joji R. Evaluation of antibacterial activity of the leaf and flower essential oils of Gliricidia sepium from South India. Int J Appl Pharm 2010;2:20-2.

\section{How to cite this article}

- Venkanna Banothu, Uma Adepally, Jayalakshmi L. In vitro total phenolics, flavonoids contents, antioxidant and antimicrobial activites of various solvent extracts from the medicinal plant Physalis minima Linn. Int J Pharm Pharm Sci 2017;9(3):192-198. 